\title{
Factors Influencing the Difference between Indonesian Case- Based Group Reimbursement and Medical Cost for Patients with Chronic Renal Disease Cases in Kasih Ibu Hospital, Surakarta
}

\author{
Mardhatillah',3), Didik Tamtomo'), Bhisma Murti3) \\ 1)Kasih Ibu Hospital, Surakarta, Central Java \\ 2)Faculty of Medicine, Universitas Sebelas Maret \\ 3)Masters Program in Public Health, Universitas Sebelas Maret
}

\begin{abstract}
Background: JKN program has stipulated the INA CBGs reimbursement for the payment of treatment in referral health facilities, including for chronic renal disease which is a disease burden. This study aimed to analyze factors influencing the difference between Indonesian case-based group reimbursement and medical cost for patients with chronic renal disease cases in Kasih Ibu Hospital, Surakarta.

Subjects and Method: The study design was an analytic observational with cross sectional design. The study was conducted in Kasih Ibu Hospital Surakarta in August-October, 2017. With a total of 231 subjects sample which was selected by using proportional random sampling. The dependent variable was the difference between Indonesian case-based group reimbursement and medical cost. The independent variables were length of stay, type of class, medical treatment/ surgery, ICU treatment, and medication use. The data were analyzed using multiple linear regression.

Result: INA CBGs reimbursement (mean= Rp 6,120,000; $\mathrm{SD}=\mathrm{Rp} 2,330,000$ ) paid by BPJS Kesehatan was lower than actual hospital's medical care cost (mean $=\mathrm{Rp} 7,070,000 ; \mathrm{SD}=\mathrm{Rp}$ $4,650,000)$. Factors profitable for hospitals were medical treatments/ surgery $(b=0.032 ; p=$ $0.552)$. Factors that inflicted financial loss were class 1 care $(b=-0.104 ; p=0.094)$, class 2 care $(b=$ -0.033; $\mathrm{p}=0.590)$ compared to class 3 care, length of stay $(b=-0.541 ; p<0.001)$, medication use in accordance with national formulation $(b=-0.183 ; p=0.008)$ and the use of ICU $(b=-0.045 ; p=$ 0.543). Patients who upgraded the class type (mean $=\mathrm{Rp} 5,526,074 ; \mathrm{SD}=\mathrm{Rp} 1,449,621$ ) was higher than hospital's medical cost for class 2 (mean= Rp 3,933,767; $\mathrm{SD}=\mathrm{Rp} 1,887,900$ ).

Conclusion: Mean of INA CBGs reimbursement on inpatient care of chronic renal disease is lower than the mean of hospital's medical care cost. Length of stay and doctors' compliance in using national medication formulation are important determinants to increase medical care cost. Hospital obtains profit from patients who upgrade type of class.
\end{abstract}

Keywords: care cost, INA CBGs reimbursement, chronic renal disease

\section{Correspondence:}

Mardhatillah. Kasih Ibu Hospital, Surakarta, Central Java. Email: mardhatillah.bws@gmail.com. Mobile: 089510610891.

\section{BACKGROUND}

Chronic Renal Disease (CRD) is an important global health issue (KDOQI, 2002). In the last ten years the CRD cases are escalating in Indonesia (IRR, 2007). The soaring number of CRD cases and keep on increasing is a disease burden since the social economic impact faced by family, society, nation and healthcare system. The endstage of CRD is called Chronic Renal Failure which needs help in filtering blood called as hemodialysis. The treatment for CRD patients related to the increasing medical care cost, $65-77 \%$ depends on the stage (Brown et al, 1999). The increasing prevalence of CRD new cases is followed by 
the utilization of advanced health facilities and the amount of expense should be spent for medical care. The increasing cost of CRD treatment which is considerable for patients and health facilities, requires a systematic effort that is able to secure society also providers from the unexpected financial burden.

Hospitals as one of the advanced health facilities have calculated the medical care cost based on components namely unit cost, medical service, non-medical, development plan, and the expected profit. The cost is later used as the reimbursement of service cost implemented in the hospital. Based on the morbidity data of Kasih Ibu hospital in 2016 there was an increasing number of CRD inpatients care by $35 \%$ compared to 2015. The indications of CRD inpatient care truly vary, especially is caused by its complication such as anemia with $\mathrm{Hb}<7 \mathrm{~g} / \mathrm{dL}$, extreme shortness of breath because of cardiovascular complication or hypertension heart disease, hyperkalemia, dyspepsia from uremia that is caused by inadequate dialysis or the failure of low protein diet, repairing access for dialysis and making a new access since the old one is disappear or no longer feasible to use. The financing sources for inpatient care that are mostly used in Kasih Ibu hospital are BPJS Kesehatan with a total of $53 \%$, followed by out-of-pocket payment $3 \%$, private-owned insurance $14 \%$, coordination of benefit (COB) with BPJS Kesehatan $1 \%$.

The addition of advanced health facilities which collaborate with BPJS especially private-owned hospitals in Central Java province and Surakarta in particular surely turns to a competitor for the existing hospitals. It is also indicating that hospitals are demanded to be more efficient and effective in organizing medical care to be able to survive in the competition era among hospitals in receiving JKN patients. Moreover, it is realized that all citizens are obliged to be JKN members in the upcoming 2019 (UU No.11/2014).

During 3 years of JKN implementation, there are changes upon policies namely the amendment of Health Minister's Regulation No.52/ 2014 to Health Minister's Regulation No.64 /2016 on the subject of The Amendment on Health Minister's Regulation No.52 on the subject of Service Tariff Standard in the Organization of Health Insurance Program. The amendment of Health Minister's Regulation more or less generates uneasiness especially for hospitals as the provider since there are several tariffs that are declining yet there are others that are increasing. Furthermore, disagreement occurs between medical care cost and INA CBG's reimbursement. Kompasiana.com stated that there are gaps between hospitals' cost of care and CBG's payment system that results in hospitals should endure financial risks (Rinawati, 2015). On the other side, Republika online news stated that unit cost in INA CBG's does not cause financial loss to the hospitals (Riadi, 2016). Hospitals that can compress production cost of medical care for certain diagnosis groups hence the average cost (unit cost) per patient is lower than INA CBG's reimbursement, may obtain profit from CRD patients care by means of hemodialysis. In contrast, if unit cost per patient of CRD is higher than INA CBG's then hospitals will endure the loss.

Based on the background it was important to study whether there is discrepancy or distinction between the average cost of CRD inpatient care undergone by hospital and the tariff of CRD inpatient care determined by BPJS Kesehatan. It was also important to study factors that influence the distinctions. 


\section{SUBJECTS AND METHOD}

The study was an analytic observational with cross sectional approach. The study was conducted in Kasih Ibu Hospital Surakarta which was a type B private-owned non-teaching hospital. The study was conducted in August-October 2017. There were a total of 231 subjects with proportional random sampling technique. Data collection was conducted by using observation on patients' medical record and costing data that has been verified by BPJS Kesehatan. INA CBGs' codes used for chronic renal diseases including: N-4-10-I, N-4-10II, N-4-10-III, N-4-16-I, N-4-16-II, N-4-16III, N-1-12-I, N-1-12-II, N-1-12-III. The dependent variable was the difference between INA CBGs' reimbursement with hospital's medical care cost for inpatient care of chronic renal disease cases. Independent variables include type of class, length of stay, medical treatments/ surgeries, medication use in accordance with the national formulation and the use of ICU.
Data analysis used multiple linear regressions.

\section{RESULT}

\section{Characteristics of study subjects}

The study result toward the characteristics frequency distribution of 200 study subjects showed that there were more male than female subjects. Most subjects were above 35 years. It could be seen in Table 1 . Characteristics frequency distribution of 31 study subjects who upgraded from patients of class 3 to class 2 could be seen in Table 2 . Table 1. Characteristics of the study subjects based on age and sex categories

\begin{tabular}{lcc}
\hline Characteristics & N & \% \\
\hline Sex Categories & & \\
Male & 105 & 52.5 \\
Female & 95 & 47.5 \\
Age & & \\
20 - 35 years & 17 & 8.5 \\
$\geq 35$ years & 183 & 91.5 \\
\hline
\end{tabular}

Table 2. Characteristics of study subjects for patients who upgraded the type of class from class 3 to class 2 for inpatient care of CRD cases

\begin{tabular}{llcc}
\hline \multicolumn{1}{c}{ Characteristics } & \multicolumn{1}{c}{ Category } & $\mathbf{N}$ & \% \\
\hline Sex categories & Male & 19 & 61.2 \\
\multirow{2}{*}{ Age } & Female & 12 & 38.7 \\
& 20 - 35 years & 3 & 9.68 \\
& $\geq 35$ years & 28 & 90.32 \\
\hline
\end{tabular}

Table 3. Description of variables of the study

\begin{tabular}{lccccc}
\hline \multicolumn{1}{c}{ Variables } & n & Mean & SD & Minimum & Maximum \\
\hline INA CBGs reimbursement (x Rp 1,000,000) & 200 & 6.12 & 2.33 & 3.31 & 12.47 \\
Hospital cost of care (x Rp1,000,000) & 200 & 7.07 & 4.65 & 1.27 & 38.57 \\
Length of stay (day) & 200 & 3.71 & 1.68 & 1 & 9 \\
Difference of tariff (x Rp 1,000,000) & 200 & -0.96 & 0.96 & -2.61 & 5.08 \\
\hline
\end{tabular}

\section{Univariate Analysis}

Description of univariate study on variables of the study explained the general description of each variable of the study that consisted of INA CBGs reimbursement, hospital's medical care cost, the difference of tariff on inpatient care of CRD cases in million rupiah unit, and length of stay in days. It can be seen in Table 3 .

Table 3 showed that mean of INA CBG's reimbursement for inpatient care of Chronic Renal Disease cases was smaller than the mean of medical care cost at Kasih Ibu Hospital with tariff difference was 
minus Rp 960,000. The length of stay ranged from 1 day at the minimum and 9 days at the maximum, with the average length of stay was 4 days.

Categorical data that included the type of class, with or without medical treatment/ surgery, the use of ICU and the use of medicine in accordance with JKN national formulation was presented in Table 4.

\section{Bivariate Analysis}

The bivariate analysis explains about the association of one variable with another variable. The variables presented were the difference between INA CBGs' reimbursement and hospital's medical care cost also doctors' compliance in using medicine in accordance with JKN National Formulation. It can be seen in Figure 1 and 2.

Table 4. Description of Variables of the Study

\begin{tabular}{|c|c|c|c|}
\hline Variables & Category & $\mathbf{n}$ & $\%$ \\
\hline \multirow[t]{3}{*}{ Type of Class } & Class 1 & 80 & 40 \\
\hline & Class 2 & 56 & 28 \\
\hline & Class 3 & 64 & 32 \\
\hline \multirow[t]{3}{*}{ Level of Severity } & Mild & 64 & 32 \\
\hline & Moderate & 115 & 57.5 \\
\hline & Severe & 21 & 10.5 \\
\hline \multirow{2}{*}{ Medical treatment/ Surgery } & Yes & 176 & 88 \\
\hline & No & 24 & 12 \\
\hline \multirow[t]{2}{*}{ Use of ICU } & Yes & 29 & 14.5 \\
\hline & No & 171 & 85.5 \\
\hline The Use of Medicine in accordance & Yes & 178 & 89.4 \\
\hline with National Formulation & No & 21 & 10.6 \\
\hline
\end{tabular}

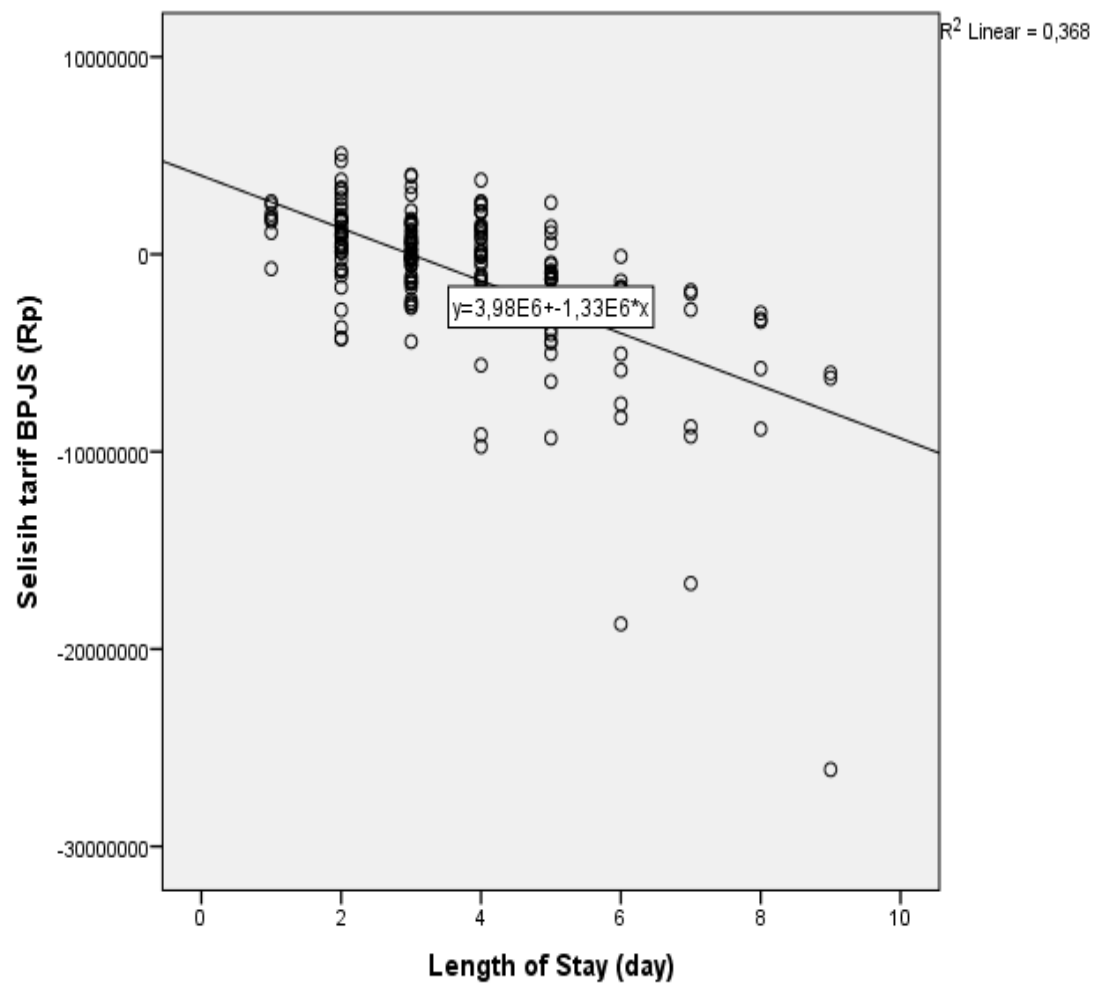

Figure 1. Scatter plot histogram on the association between length of stay and BPJS reimbursement difference 


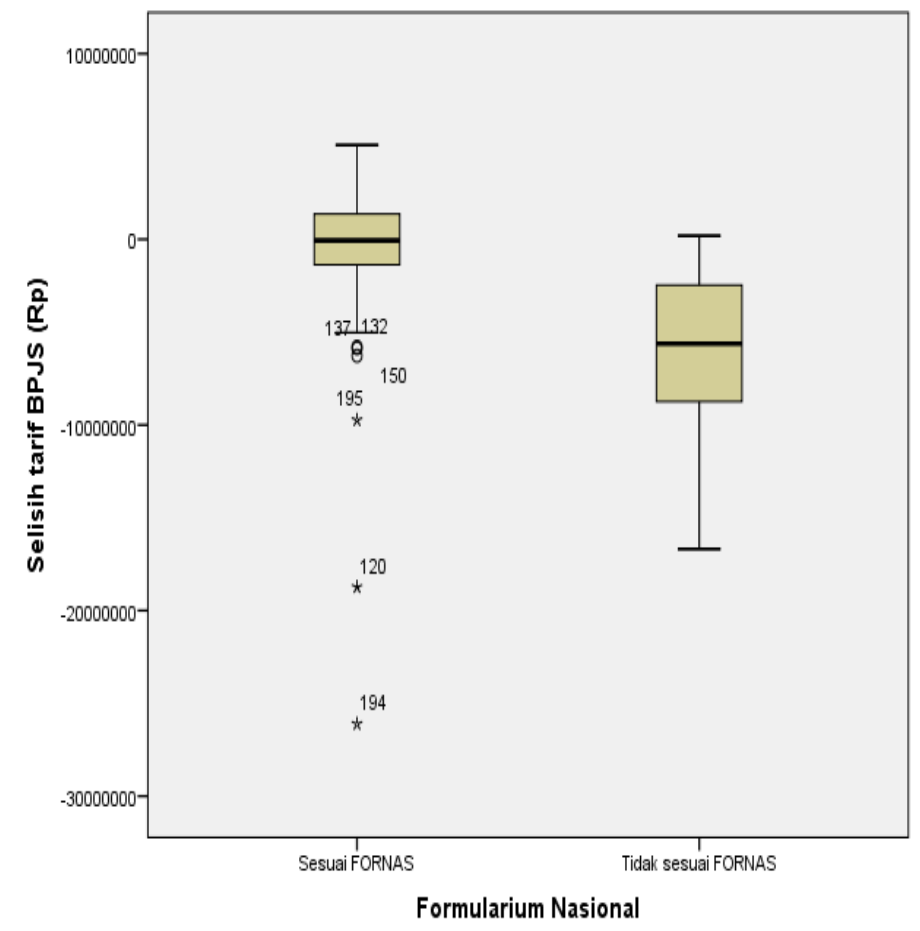

Figure 2. Box plot histogram on the association of the use of national formulation and BPJS reimbursement difference

Figure 1. explained that there was a negative association between length of stay with the difference of INA CBGs' reimbursement and hospital's care cost. Figure 2 explains that there was a negative association between doctors' compliance in using medicine in accordance with the national formulation with the difference between INA CBGs' reimbursement and hospital's care cost.

\section{Multivariate Analysis}

The multivariate analysis explains the association of more than one independent variables. The analyzed variables include the type of class, length of stay (LOS), medical treatments/ surgery, the use of ICU and the use of medicine in accordance with JKN National Formulation.

Table 5 showed that there was a negative association between the difference of INA CBGs' reimbursement and medical care cost of CRD case inpatient care with the length of stay which was statistically significant. Each 1-day addition of the length of stay would cause a financial loss for the hospital as much as Rp. 1,187,602 $(b=-0.542$; CI $95 \%=-1,436,148$ to 939,055; $\mathrm{p}<0.001$ ).

There was negative association between the difference of tariff with doctors' in compliance in using medicine in accordance with JKN National Formulation ( $b=$ 0.183 ; $95 \% \mathrm{CI}=-3,844,102$ to $579,120 \mathrm{p}=$ o.o08). Doctors' in compliance in using medicine in accordance with National Formulation might cause a financial loss for the hospital as much as Rp 2,220,789.

There was a positive association between tariff difference with medical treatment/ surgery $(b=0.032 ; 95 \% \mathrm{CI}=-847,876$ to $1,581,720 ; \mathrm{p}=0.552$ ) however it was statistically insignificant. Also with the use of ICU $(b=-0.045 ; 95 \% \mathrm{CI}=-1,994,371$ to $1,053,382 ; p=0.543)$. Class 1 care generated financial loss of $\mathrm{Rp} 783,260$ compared to class $3(b=-0.104 ; 95 \% \mathrm{CI}=-1.70$ to $0.13 ; \mathrm{p}=0.094)$. 
Journal of Health Policy and Management (2017), 2(2): 117-127

https://doi.org/10.26911/thejhpm.2017.02.02.03

Table 5. Result of multiple linear regression analysis on the association between the difference of INA CBGs' reimbursement with medical care cost of CRD cases inpatient care and the factors that influence

\begin{tabular}{lrccc}
\hline \multirow{2}{*}{ Independent Variables } & \multirow{2}{*}{$\mathbf{b}$} & \multicolumn{2}{c}{$\mathbf{9 5 \%}$ CI } & \multirow{2}{*}{ p } \\
\cline { 3 - 4 } & & Lower Limit & Upper Limit & \\
\hline Constanta & 663422 & 1739775 & 3066619 & 0.587 \\
Class 2 & -267983 & -1246942 & 710976 & 0.590 \\
Class 1 & -783260 & -1701513 & 134993 & 0.094 \\
Length of stay (days) & -1187602 & -1436148 & -939055 & 0.000 \\
With medical treatment/surgery & 366922 & -847876 & 1581720 & 0.552 \\
ICU use & -470494 & -1994371 & 1053382 & 0.543 \\
Medicine administration not fit & -2211611 & -3844102 & 579120 & 0.008 \\
national formulation & & & & \\
Patients' age (years) & 10990 & -21434 & 43415 & 0.505 \\
Complication & -1720828 & -2820160 & -621496 & 0.002 \\
Sex categories & 259362 & -492168 & 1010894 & 0.497 \\
Level of severity & 1643003 & 940418 & 2345588 & 0.000 \\
n observation = 200 & & & & \\
Adjusted $\mathrm{R}^{2}=50.4 \%$ & & & & \\
p $<$ 0.001 & & & & \\
\hline
\end{tabular}

There was negative association between class 2 care $(b=-0.03$; CI 95\%= $1,246,942$ to 710,$976 ; \mathrm{p}=0.590$ ) with tariff difference however it was statistically insignificant. There was positive association between tariff difference with level of severity and statistically significant $(b=0.27$; 95\% CI $=940,418$ to $2,345,588 ; \mathrm{p}<0.001)$.

Table 6. Description of variable of the study for patients who upgraded the type of class from class 3 to class 2 of inpatient care of CRD cases

\begin{tabular}{lrrrrr}
\hline \multicolumn{1}{c}{ Variables } & N & Mean & \multicolumn{1}{c}{ SD } & Minimum & Maximum \\
\hline $\begin{array}{l}\text { BPJS reimbursement for class 2 } \\
\text { (rupiah) }\end{array}$ & 31 & $5,526,074$ & $1,449,621$ & $3,976,600$ & $8,686,600$ \\
$\begin{array}{l}\text { BPJS reimbursement for class 3 } \\
\text { Hospital's care cost for class 2 }\end{array}$ & 31 & $4,619,135$ & $1,199,608$ & $3,313,800$ & $7,238,900$ \\
$\begin{array}{l}\text { Difference between hospital's Care Cost } \\
\text { for class 2 and BPJS reimbursement for } \\
\text { class 3 }\end{array}$ & 31 & $3,933,767$ & $1,887,900$ & $1,345,207$ & $1,345,207$ \\
$\begin{array}{l}\text { Difference between BPJS reimburse- } \\
\text { ment for class 2 and class 3 }\end{array}$ & 31 & 906,938 & $1,19, .608$ & $-3,372,901$ & $4,732,493$ \\
& & & & & \\
\hline
\end{tabular}

DISCUSSION

1. INA CBGs' reimbursement for inpatient care of CRD compared to medical care cost in Kasih Ibu Hospital, Surakarta

The analysis result found that INA CBGs' reimbursement for inpatient care of CDR
Study subjects who upgraded the type of class showed that the mean of INA CBGs' tariff of inpatient care of CRD cases for class 2 patients was higher than medical care cost of class 2 at Kasih Ibu hospital, Surakarta. It was explained in Table 6. cases according to the type of class was lower than medical care cost in Kasih Ibu Hospital Surakarta. The result of the study is in line with a study by Hudayani (2016) that showed there is a distinction between INA CBGs' reimbursement and hospital's real cost in hemorrhagic stroke. In which 
the total of INA CBGs' reimbursement is lower than hospital's real cost.

Calculating the tariff and the cost of medical care in healthcare facilities such as private-owned hospitals is an important aspect in the era of prospective payment of current JKN program. Medical care cost spent by the hospital to provide treatment for patients is truly varied. The variation is influenced by the number of resources used in particular for inpatient care activities as well as the value or price determined by the hospital for various service given (Sloan, 2002). Payment with INA CBGs system implies that hospital with the team of doctors should set fix cost and variable cost of what must be spent by the hospital for the third party (Thabrany, 2014). The determination is made based on clinical pathways. Therefore, it is important for the hospital to have and make standard procedure in disease management with clinical pathway, particularly for CRD cases. So that hospital can perform quality control and cost control in providing optimal, effective and efficient care.

\section{Advantage and disadvantage en- dured by hospital related to claim for INA CBGs reimbursement}

The analysis result found that INA CBGs' reimbursement was lower than hospital's medical care cost for inpatient care of CDR case according to the type of class, hence hospital endured the financial loss. The previous study found that INA CBGs' reimbursement was higher than hospital's tariff regardless the diagnosis/ case of disease (Rahayuningrum, 2016).

Payment of INA CBGs claim gives advantages in facilitating the revenue calculation for the hospital. The difference between advantages and disadvantages of INA CBGs' reimbursement implementation in private-owned hospitals is generated by the various amount of medical care bill for each hospital. The amount of bill agreed in INA CBGs reimbursement for a certain diagnosis and procedure should be agreed by all hospitals in a certain region through hospital organization which is the local Indonesia Hospital Association (PERSI), therefore PERSI should improve its role in this matter. In addition, one of the factors considered in hospital's annual operational budget planning is the amount of profit possibly obtained to subsequently develop hospital.

Tamtomo (1995) explained that hospital should be able to maintain its sustainability through surplus or profit without neglecting the social functions. Furthermore, as an effort to consistently have competitive profit compare to other healthcare providers, the hospital should improve cost-effectiveness and cost-effectiveness without reducing service quality, having data and information flow which help in optimizing resources and creating new options in the service quality improvement (Hidayat, 2016).

\section{Association between type of class with tariff difference}

The result of the analysis showed that medical care in class 1 and class 2 had a negative association and statistically come close to significant compared to medical care in class 3with a growing difference between the tariff and hospital's medical care cost.

INA CBG's reimbursement has a stipulated class-based tariff that includes class 1, class 2, and class 3. In line with Appendix of Health Minister's Regulation No. 64/ 2016 on the subject of the Amendment on Health Minister's Regulation No. 52/2014 on the subject of Healthcare Tariff Standard in the Administration of Health Insurance Program, hence there is tariff difference in each type of class. The higher the type of class is, the bigger amount of INA CBGs' in rupiah will be. It is in line with the 
Journal of Health Policy and Management (2017), 2(2): 117-127

https://doi.org/10.26911/thejhpm.2017.02.02.03

tariff of inpatient room at the hospital, the higher the type of class is, the more expensive the tariff of inpatient care room will be. The difference of inpatient room tariff is determined by the facilities, convenience, as well as privacy provided by the hospital. However, the provided care, medication, as well as service-related to disease management by doctors, nurses, and other health workers are not different.

\section{Association between length of stay with tariff difference}

The result of the analysis showed that there was a negative relationship and statistically significant between the length of stay at hospital for CDR cases and the tariff difference between INA CBGs and hospital medical care cost. Aggarwal et al. (2014) explained that the increasing length of stay of inpatient care for CDR cases will increase inpatient medical care cost spent with the mean of LOS for CRD cases is 5 up to 6 days.

The length of stay for various diagnosis is varied and one of the indicators for medical care at the hospital which is regularly measured for calculating the level of utilization and financial report for policy making in management and directors level. The ideal length of stay according to Health Department in 2015 was $3-12$ days. In the study, the mean of length of stay for CRD cases was 4 days. Therefore, from the economy aspect, the longer the LOS is meant the higher the cost should be spent by the hospital since INA CBGs' reimbursement is permanent in nature. From the medical aspect, the longer the LOS is may show insufficient medical quality since patients should be treated longer or it takes a long time to recover. Whether the LOS value is ideal for certain disease diagnosis can be observed if the hospital has implemented and possessed Clinical Pathway for every disease diagnosis.

\section{Association between medical treat- ment/ surgery tariff difference}

The analysis result showed that there was positive association which was insignificant between medical treatment/surgery with the tariff difference of INA CBGs' and medical care cost of inpatient care for CRD cases at the hospital. In accordance with Health Minister's Regulation No.76/2016 on the subject of INA CBGs' guidelines in JKN implementation their difference in the structure of case-group code between procedural inpatient and non procedural inpatient. Procedural inpatient includes inpatient with surgery such as the making or installation of vascular access for hemodialysis patients by a cardiothoracic surgeon, whereas non-procedural inpatient includes care with non-surgery medical treatments such as hemodialysis and blood transfusion. Thus INA CBGs' reimbursement has accommodated the increasing medical care cost which is higher for procedural inpatient care than non-procedural inpatient care.

\section{Association between ICU utiliza- tion with tariff difference}

The analysis result showed that there was negative association which was insignificant between the use of inpatient care in ICU with tariff difference of INA CBGs' and medical care cost for CRD cases at the hospital. It different from the previous study that showed that there was a significant association between ICU care with hospital's tariff (Rahayuningrum, 2016). Karabatsou et al. (2016) explained that the total cost of ICU care is greatly influenced by 3 things namely the length of stay in ICU, disease severity, the need for mechanic ventilator and the use of continuous dialysis or CRRT (Continous Renal Replacement Therapy). Hence it explains that the difference of study results may be inflicted by the difference of diagnosis, disease severity, 
and the absence of CRRT facilities at the hospital. Therefore, dialysis is generally performed with 4-4.5 hours method in ICU or in Hemodialysis Unit without consuming longer time.

\section{Association between use of medi- cine in accordance with JKN natio- nal formulation with tariff differ- ence}

The analysis result showed that there was a negative association which was significant between compliance in using medicine by National Formulation with tariff difference between INA CBGs' and hospital's medical care cost. It means that the more doctors who do not use medicines in accordance with National Formulation the greater the loss endured by the hospital.

Based on the Republic of Indonesia Health Minister's Decree No.328/2013 the most of the medicines categorized into National Formulation are generic medicines. However, in reality, it is difficult especially for private-owned hospitals to obtain the medicines in compliance with National Formulation by means of e-purchasing as it is explained in Health Minister's Regulation No.28/2014 on the subject of medicines procurement for $\mathrm{JKN}$ patients care. The problem is still becoming a hindrance up to now after JKN has proceeded for more than 3 years. Hence the hospitals generally will conduct their own medicine procurement independently by seeking for generic medicines with prices come close to the JKN national formulation prices. A study by Kalo et al. (2014) explains that generic medicines use will increase patients' accessibility to obtain therapy, in addition, to suppress and cut down the expenses of pharmacy or medicines cost. The similar thing is also being followed by the policy on JKN National Formulation usage in Indonesia with one of the purpose is to control public healthcare cost.
Factors that influence the policy consist of patients, doctors, pharmacists, and the manager of formulation makers (Howard et al., 2017). Furthermore, it is explained in the above study that Medical Specialists are likely to prescribe more for patent medicines.

It is in accordance with the result of the current study that there were still study subjects who did not obtain medicines in compliance with National Formulation (generic medicine) they get the patent medicine instead. The reason is that there are doctors and pharmacists who perceive that generic medicines are not as good as the original or patent medicines (Dunne, 2014). For that it takes education and more studies on generic medicine's effectiveness for the value-based medicine thus it can increase the compliance and will of health practitioners especially Medical Specialists to prescribe generic medicines.

\section{Association between amount of cost for patients who upgrade the type of class at hospital with tariff difference}

The analysis result showed that the mean of INA CBGs' reimbursement of inpatient care for CRD cases in class 2 was higher than the mean of patients' medical care cost of class 2 in Kasih Ibu Hospital Surakarta. It means the hospital obtain profit from patients who upgrade from class 3 to class 2 of inpatient care for CRD cases. The amount of cost sharing for patients who upgrade the type of class is regulated in Health Minister's Regulation No.64/ 2016. For patients who upgrade the type of class from class 3 to class 2, the patients should pay the tariff difference of INA CBGs for the class they occupy, deducted by the tariff of INA CBGs' of class they deserve to be in.

The limitation of the study among others are that the study was conducted without considering other factors of the 
cost component, that probably may influence the medical care cost such as the medical fee of medical workers (doctors and nurses) and the study was conducted without concerning the patients' satisfaction level toward the care performed in Kasih Ibu Hospital, Surakarta.

\section{REFERENCE}

Aggarwal S, Topaloglu H, Kumar S (2014). Cost of inpatient hospitalization for chronic kidney Disease in the United States. Value in Health: Journal of International Society for Pharmacoeconomics and Outcomes Research, 1: A293.

Brown JB, Pedula KL, Balest AW (1999). The progressive cost of complication in type 2 diabetes mellitus. Arch Intern Med Journal. 159(16): 187380.

Dunne S, Shannon B, Hannigan A, Dunne C, Cullen W (2014). Physician and pharmacist perceptions of generic medicines: What they think and how they differ. Health Policy Journal, 116: 214-223.

Hidayat AM, Pribadi F, Marwati T (2016). Analisis Unit Cost Tindakan Appendektomi menggunakan Metode Activity Based Costing. Jurnal Asosiasi Dosen Muhammadiyah Magister Manajemen Rumah Sakit, UMY.

Howard JN, Harris I, Frank G, Kiptanui Z, Qiun J, Hansen R (2017). Influencers of Generic Drug Utilization: A Systematica Review. Research in Social and Administrative Pharmacy. Diakses di http://10.1016/j.sapharm.2017.08.00 1 tanggal 10 November 2017.

Hudayani M, Andayani TM, Fudholi A. (2016). Komparasi Biaya Riil dengan Tarif INA CBGs dan Analisis Komponen Biaya yang Berpengaruh pada Pasien Stroke Hemoragi Rawat Inap
Peserta JKN di Rumah Sakit Kabupaten Pekalongan. Thesis s2 Farmasi UGM. Yogyakarta.

Indonesia Renal Registry (2015). 8th Report of Indonesia Renal Registry 2015. PERNEFRI 2015.

Karabatsou D, Tsironi M, Tsigou E, Boutzouka E, Katsaulas T, Baltopaulus G. (2016). Variable Cost of ICU Care: A Micro-Costing Analysis. Intensive Critical Care Nursing Journal, 35: 6673 .

Kalo Z, Harsanyi A, Vamossy I (2014). Investment Aspect of Generic Drug Policies in Countries with Severe Resource Constraints. Value in Health: Journal of International Society for Pharmacoeconomics and Outcomes Research, 17: A500.

National Kidney Foundation (2002). K/ DOQI Clinical Practice Guidelines for Chronic Kidney Disease: Evaluation, Classification, and Stratification. Am J Kidney Dis 39:S1-S266.

Peraturan Menteri Kesehatan Republik Indonesia Nomor 64 tahun 2016 tentang Perubahan atas Peraturan Menteri Kesehatan No. 52 Tahun 2014 tentang Standar Tarif Pelayanan Kesehatan Dalam Penyelenggaraan Program Jaminan Kesehatan.

Rinawati W (2015). Demotivasi atau Memotivasi. Kompasiana.com. Diakses di www.kompasiana.com/ pada 5 Juni 2017.

Riady M (2017). Tak Beralasan Jika RS Swasta Tolak BPJS Kesehatan. Diakses di www.republika.co.id pada tanggal 7 Juni 2017.

Rahayuningrum O, Tamtomo DG, Murti B (2016). Comparison between Hospital Inpatient Cost and INA-CBGs reimbursement of Inpatient Care in the National Health Insurance Scheme in Solo, Karanganyar, Boyolali District 
Central Java. Journal of Health Policy and Management 1(2): 102-112.

Sloan FA (2002). Valuing Health Care: Cost, Benefits and Effectiveness of Pharmaceuticals and Other Medical Technologies. United Kingdom: The Press Syndicate of the University of Cambridge.

Tamtomo DG (1995). Analisa Pembebanan Biaya untuk Menentukan Tarip Satuan Pelayanan pada Rumah Sakit Panti Waluyo, Surakarta. Laporan Peneliti- an Mandiri. Fakultas Kedokteran Universitas Sebelas Maret, Surakarta.

Thabrany H (2014). Jaminan Kesehatan Nasional. Jakarta: Raja Grafindo Persada.

Undang-undang No.11 Tahun 2014 tentang Badan Penyelenggara Jaminan Sosial. 